\title{
Natural and Drug Rewards Act on Common Neural Plasticity Mechanisms with $\Delta$ FosB as a Key Mediator
}

\author{
Kyle K. Pitchers, ${ }^{1,2}$ Vincent Vialou, ${ }^{3}$ Eric J. Nestler, ${ }^{3}$ Steven R. Laviolette, ${ }^{1}$ Michael N. Lehman, ${ }^{1,2,4}$ \\ and Lique M. Coolen ${ }^{1,2,5}$ \\ ${ }^{1}$ Department of Anatomy \& Cell Biology, Schulich School of Medicine and Dentistry, University of Western Ontario, London, Ontario N6A 3K7, Canada, \\ ${ }^{2}$ Department of Molecular \& Integrative Physiology, University of Michigan, Ann Arbor, Michigan 48109, ${ }^{3}$ Fishberg Department of Neuroscience and \\ Friedman Brain Institute, Mount Sinai School of Medicine, New York, New York 10029, and Departments of ${ }^{4}$ Neurobiology and Anatomical Sciences and \\ ${ }^{5}$ Physiology and Biophysics, University of Mississippi Medical Center, Jackson, Mississippi 39216
}

Drugs of abuse induce neuroplasticity in the natural reward pathway, specifically the nucleus accumbens (NAc), thereby causing development and expression of addictive behavior. Recent evidence suggests that natural rewards may cause similar changes in the NAc, suggesting that drugs may activate mechanisms of plasticity shared with natural rewards, and allowing for unique interplay between natural and drug rewards. In this study, we demonstrate that sexual experience in male rats when followed by short or prolonged periods of loss of sex reward causes enhanced amphetamine reward, indicated by sensitized conditioned place preference for low-dose ( 0.5 $\mathrm{mg} / \mathrm{kg}$ ) amphetamine. Moreover, the onset, but not the longer-term expression, of enhanced amphetamine reward was correlated with a transient increase in dendritic spines in the NAc. Next, a critical role for the transcription factor $\Delta$ FosB in sex experience-induced enhanced amphetamine reward and associated increases in dendritic spines on NAc neurons was established using viral vector gene transfer of the dominant-negative binding partner $\Delta$ JunD. Moreover, it was demonstrated that sexual experience-induced enhanced drug reward, $\Delta$ FosB, and spinogenesis are dependent on mating-induced dopamine D1 receptor activation in the NAc. Pharmacological blockade of D1 receptor, but not D2 receptor, in the NAc during sexual behavior attenuated $\Delta$ FosB induction and prevented increased spinogenesis and sensitized amphetamine reward. Together, these findings demonstrate that drugs of abuse and natural reward behaviors act on common molecular and cellular mechanisms of plasticity that control vulnerability to drug addiction, and that this increased vulnerability is mediated by $\Delta$ FosB and its downstream transcriptional targets.

\section{Introduction}

Natural reward behaviors and drug reward converge on a common neural pathway, the mesolimbic dopamine (DA) system, in which the nucleus accumbens (NAc) plays a central role (Kelley, 2004). Drugs of abuse induce neuroplasticity in the mesolimbic system, which plays a putative role in the transition from drug use to drug addiction (Hyman et al., 2006; Kauer and Malenka, 2007; Kalivas, 2009; Chen et al., 2010; Koob and Volkow, 2010; Wolf, 2010a; Mameli and Luscher, 2011). It has been hypothesized that drugs and natural rewards do not activate the same neurons in the mesolimbic system, and thus that drugs uniquely activate and alter this circuit (Cameron and Carelli, 2012). However, it has become increasingly clear that natural and drug rewards affect the mesolimbic system in both similar and different ways that

Received Oct. 16, 2012; revised Dec. 12, 2012; accepted Dec. 23, 2012.

Author contributions: K.K.P., M.N.L., and L.M.C. designed research; K.K.P. performed research; V.V., E.J.N., and S.R.L. contributed unpublished reagents/analytic tools; K.K.P. analyzed data; K.K.P. and L.M.C. wrote the paper.

This work was supported by the Canadian Institutes of Health Research (L.M.C.), National Institute of Mental Health (E.J.N.), and Natural Sciences and Engineering Research Council of Canada (K.K.P. and L.M.C.). We thank Dr. Catherine Woolley (Northwestern University) for assistance with diolistic labeling technique.

The authors declare no competing financial interests.

Correspondence should be addressed to Dr. Lique M. Coolen, Department of Physiology and Biophysics, University of Mississippi Medical Center, 2500 North State Street, Jackson, MS 39216. E-mail: Icoolen@umc.edu.

DOI:10.1523/JNEUROSCI.4881-12.2013

Copyright $\odot 2013$ the authors $\quad 0270-6474 / 13 / 333434-09 \$ 15.00 / 0$ allow for an interplay between natural reward, specifically sex reward, and the effects of drugs of abuse (Frohmader et al., 2010a; Pitchers et al., 2010a; Olsen, 2011).

Sexual behavior is highly rewarding (Tenk et al., 2009), and sexual experience causes sensitized drug-related behaviors, including cross-sensitization to amphetamine (Amph)-induced locomotor activity (Bradley and Meisel, 2001; Pitchers et al., 2010a) and enhanced Amph reward (Pitchers et al., 2010a). Moreover, sexual experience induces neural plasticity in the NAc similar to that induced by psychostimulant exposure, including increased dendritic spine density (Meisel and Mullins, 2006; Pitchers et al., 2010a), altered glutamate receptor trafficking, and decreased synaptic strength in prefrontal cortex-responding NAc shell neurons (Pitchers et al., 2012). Finally, periods of abstinence from sexual experience were found to be critical for enhanced Amph reward, NAc spinogenesis (Pitchers et al., 2010a), and glutamate receptor trafficking (Pitchers et al., 2012). These findings suggest that natural and drug reward experiences share common mechanisms of neural plasticity, which in turn influence vulnerability to substance abuse.

The goal of the current study was to determine the cellular mechanisms mediating sex experience-induced plasticity, which in turn cause enhanced drug reward. Specifically, the role of the transcription factor $\Delta$ FosB was investigated because it is involved in the effects of both natural and drug rewards (Nestler et al., 
2001; Werme et al., 2002; Olausson et al., 2006; Wallace et al., 2008; Hedges et al., 2009; Pitchers et al., 2010b). In addition, the role of dopamine D1 receptors (D1R) for sexual experienceinduced neural plasticity was examined because NAc $\Delta$ FosB induction and increased spine density after psychostimulant administration are expressed in D1R-containing neurons (Lee et al., 2006; Kim et al., 2009) and dependent on D1R activation (Zhang et al., 2002).

Here, we used viral vector-mediated expression of a dominantnegative binding partner for $\Delta \mathrm{FosB}$, diOlistic labeling, and pharmacological manipulations to test the hypothesis that the crosssensitizing effects of sexual experience followed by reward abstinence on enhanced Amph reward are mediated by a D1Rdependent induction of $\Delta$ FosB in the NAc and subsequent increase of NAc spine density. Together, the findings provide evidence that natural and drug rewards share common mechanisms of neural plasticity, with $\Delta$ FosB as a critical mediator.

\section{Materials and Methods}

Animals. Adult male (225-250 g upon arrival) and female (210-220 g) Sprague Dawley rats (Charles River Laboratories) were housed in Plexiglas cages in same sex pairs throughout experiments, under temperature and humidity regulation and on a 12/12 h light/dark cycle with food and water freely available. Female partners for mating sessions were ovariectomized and received subcutaneous implants containing 5\% estradiol benzoate (Sigma-Aldrich) and injections of $500 \mu \mathrm{g}$ of progesterone (in $0.1 \mathrm{ml}$ of sesame oil; Sigma-Aldrich) $4 \mathrm{~h}$ before testing. All procedures were approved by the Animal Care and Use Committees of the University of Western Ontario and the University of Michigan and conformed to Canadian Council on Animal Care and National Institutes of Health guidelines involving vertebrate animals in research.

Sexual behavior. Mating sessions occurred during the early dark phase (between 2 and $6 \mathrm{~h}$ after onset of the dark period) under dim red illumination, in clean test cages $(60 \times 45 \times 50 \mathrm{~cm})$. Male rats mated to ejaculation during 4 or 5 daily mating sessions. Five sessions were chosen because we have previously shown that this paradigm causes long-term facilitation of sexual behavior (Pitchers et al., 2010b), cross-sensitization to Amph locomotor activity (Pitchers et al., 2010a), and reward (Pitchers et al., 2010a). Ejaculation was chosen as the endpoint of each mating session because we previously showed it to be essential for effects of sex experience on Amph locomotor sensitization (Pitchers et al., 2010a), which did not occur when animals were allowed to mate with females without display of ejaculation. Sexual behavior parameters (i.e., latency to first mount, intromission and ejaculation, and number of mounts and intromissions) were recorded as described previously (Pitchers et al., 2010b). For all experiments, sexually experienced groups were matched for sex behavior (total number of ejaculations and latency to ejaculation during each mating session). After the fifth mating session, males remained housed with same sex partners and were not allowed to mate during sex abstinence periods of 1, 7, or $28 \mathrm{~d}$. Animals that remained sexually naive were handled and housed in the same rooms as sexually experienced males. In addition, naive controls were placed in clean test cages for an hour during 5 consecutive days, without access to a receptive female.

$\Delta$ FosB expression. Animals were deeply anesthetized (sodium pentobarbital; $390 \mathrm{mg} / \mathrm{kg}$; i.p.) and perfused intracardially with $50 \mathrm{ml}$ of $0.9 \%$ saline, followed by $500 \mathrm{ml}$ of $4 \%$ paraformaldehyde (Sigma-Aldrich) in $0.1 \mathrm{M}$ phosphate buffer $(\mathrm{PB})$ for the time point and $\mathrm{DR}$ antagonist experiments. Brains were removed and postfixed for $1 \mathrm{~h}$ at room temperature in the same fixative, then stored at $4^{\circ} \mathrm{C}$ in $20 \%$ sucrose and $0.01 \%$ sodium azide in $0.1 \mathrm{M} \mathrm{PB}$. For the DR antagonist experiments, brains were removed and halved along the sagittal axis. One half was stored in PB and used for DiOlistics, and the other was processed for $\Delta$ FosB. Coronal sections $(35 \mu \mathrm{m})$ were cut with a freezing microtome (Microm H400R), collected in four parallel series in cryoprotectant solution (30\% sucrose and $30 \%$ ethylene glycol in $0.1 \mathrm{M} \mathrm{PB}$ ) and stored at $-20^{\circ} \mathrm{C}$. Free-floating sections were washed extensively with $0.1 \mathrm{M}$ PBS, pH 7.35, between incu- bations, and all steps were at room temperature. Sections were exposed to $1 \% \mathrm{H}_{2} \mathrm{O}_{2}(10 \mathrm{~min})$ and incubation solution ( $1 \mathrm{~h}$; PBS containing $0.1 \%$ BSA, Fisher; and $0.4 \%$ Triton X-100, Sigma-Aldrich). Sections were then incubated overnight in pan-FosB rabbit polyclonal antibody (1:5K; sc-48 Santa Cruz Biotechnology), previously validated (Perrotti et al., 2004, 2008; Pitchers et al., 2010b). The pan-FosB antibody was raised against an internal region shared by FosB and $\Delta \mathrm{FosB}$, and has been previously characterized to specifically visualize $\Delta$ FosB cells at the time points used in this study ( $>1$ d after stimulus) (Perrotti et al., 2004, 2008; Pitchers et al., 2010b). Next, sections were incubated in biotin-conjugated goat antirabbit IgG (1 h; 1:500 in PBS+; Vector Laboratories), avidin-biotinhorseradish peroxidase $(1 \mathrm{~h}$; ABC elite; $1: 1000$ in PBS; Vector Laboratories), and $0.02 \% 3,3^{\prime}$-diaminobenzidine tetrahydrochloride (10 min; Sigma-Aldrich) with $0.02 \%$ nickel sulfate in $0.1 \mathrm{M} \mathrm{PB}$ with hydrogen peroxide $(0.015 \%)$. Sections were mounted onto Superfrost plus glass slides (Fisher) and coverslipped with dibutyl phthalate xylene.

Numbers of $\Delta$ FosB-IR cells were counted in the NAc shell and core within standard areas of analysis $(400 \times 600 \mu \mathrm{m})$ as previously described (Pitchers et al., 2010b). Two sections were counted per NAc subregion, averaged per animal. In the time point experiment, numbers of $\Delta$ FosB-IR cells were expressed as a fold change of the naive control group at the appropriate time point and compared between experienced and naive groups for each subregion at each individual time point using unpaired $t$ tests with a significance level of $p<0.05$. In the $\Delta$ JunD-AAV and DR antagonist experiments, a two-way or one-way ANOVA, respectively, and Holm-Sidak method were used. In addition, $\Delta$ FosB-IR cells were counted in the dorsal striatum (area of analysis: $200 \times 600 \mu \mathrm{m}$ ), immediately dorsal to the NAc and adjacent to the lateral ventricle, in all animals in the DR antagonist experiment. One-way ANOVA and $t$ tests were used to compare between groups.

DiOlistics. For the time point and $\Delta \mathrm{JunD}$ viral vector experiment, rats were perfused intracardially with $50 \mathrm{ml}$ saline $(0.9 \%)$, followed by $500 \mathrm{ml}$ of $2 \%$ paraformaldehyde in $0.1 \mathrm{M} \mathrm{PB}$. Brains were sectioned $(100 \mu \mathrm{m}$ coronal) using a vibratome (Microm) and sections stored in $0.1 \mathrm{M} \mathrm{PB}$ with $0.01 \%$ sodium azide at $4^{\circ} \mathrm{C}$. Coating of tungsten particles $(1.3 \mu \mathrm{m}$ diameter, Bio-Rad) with the lipophilic carbocyanine dye DiI $\left(1,1^{\prime}\right.$ dioctadecyl-3,3,3' $3^{\prime}$-tetramethylindocarbocyanine perchlorate; Invitrogen) was performed as previously described (Forlano and Woolley, 2010). DiI-coated tungsten particles were delivered into the tissue at 160-180 psi using the Helios Gene Gun system (Bio-Rad) through a filter with $3.0 \mu \mathrm{m}$ pore size (BD Biosciences) and allowed to diffuse through neuronal membranes in $0.1 \mathrm{M} \mathrm{PB}$ for $24 \mathrm{~h}$ while light-protected at $4^{\circ} \mathrm{C}$. Next, slices were postfixed in $4 \%$ paraformaldehyde in $\mathrm{PB}$ for $3 \mathrm{~h}$ at room temperature, washed in $\mathrm{PB}$, and mounted in frame-sealed chambers (Bio-Rad) with gelvatol containing the anti-fading agent 1,4-diazabicyclo(2,2)octane (50 $\mathrm{mg} / \mathrm{ml}$, Sigma-Aldrich) (Lennette, 1978).

DiI-labeled neurons were imaged using Zeiss LSM $510 \mathrm{M}$ confocal microscope (Carl Zeiss) and helium/neon $543 \mathrm{~nm}$ laser. For each animal, 2-5 neurons in each NAc subregion, or in the shell (based on location in relation to landmarks, including the lateral ventricle and anterior commissure) in $\triangle$ JunD-AAV and DR antagonist experiments, were used to locate a region of interest on a second order dendrite for spine quantification. For each neuron, 2-4 dendrites were analyzed to quantify a total dendritic length of 40-100 $\mu \mathrm{m}$. Dendritic segments were captured using $40 \times$ water-immersion objective at $0.25 \mu \mathrm{m}$ intervals along the $z$-axis, and a 3D image was reconstructed (Zeiss) and underwent deconvolution (Autoquant X, Media Cybernetics) using adaptive (blind) and theoretical PSF setting as recommended by the software. Spine density was quantified using the Filament module of Imaris software package (version 7.0, Bitplane). Numbers of dendritic spines were expressed per $10 \mu \mathrm{m}$, averaged for each neuron and then for each animal. Statistical differences were determined using two-way ANOVAs in the time series experiment between sexually naive and experienced animals at each time point (factors: sexual experience and NAc subregion) and in the $\Delta$ JunD experiment (factors: sexual experience and viral vector), and one-way ANOVA in the DR antagonist experiment. Group comparisons were made with the Holm-Sidak method with a significance level of $p<0.05$.

Conditioned place preference. The CPP experimental design was identical as previously described(Pitchers et al., 2010a), using an unbiased 
three-compartment apparatus (Med Associates), and unbiased design, with single pairing conditioning trial of D-Amph sulfate (Amph; Sigma-Aldrich; $0.5 \mathrm{mg} / \mathrm{ml} / \mathrm{kg}$ s.c. calculated on basis of the free base) in the paired chamber and saline in the unpaired chamber during alternate days, and performed during the first half of the light phase. Control animals received saline in both chambers.

CPP scores were calculated for each animal as the time spent (in seconds) in the paired chamber during the post-test minus the pretest. One-way ANOVAs and the Holm-Sidak method were used to compare groups in the time point experiments. Unpaired $t$ test with significance set at $p<0.05$ was used to compare Naive-Sal and Naive Amph within each time point in the time point experiment, and within each viral vector treatment in the $\Delta$ JunD experiment. In the time experiment, one-way ANOVAs and the Holm-Sidak method were used to compare the sexually experienced groups (Exp-Sal, $7 \mathrm{~d}$ Exp Amph and $28 \mathrm{~d} \operatorname{Exp}$ Amph), and unpaired $t$ test was used to compare the 2 naive groups. Two-way ANOVA and the Holm-Sidak method were used to compare all groups in the DR antagonist experiment. Two unpaired $t$ test were used to compare Naive-Sal and Naive Amph groups with each viral vector treatment condition (GFP or $\Delta$ JunD), as data were too variable in the $\Delta$ JunD groups to allow for ANOVA analysis. All significance levels were set at $p<0.05$.

Viral vector experiments. Male rats were anesthetized with ketamine ( $87 \mathrm{mg} / \mathrm{ml} / \mathrm{kg}$; i.p.) and xylazine $(13 \mathrm{mg} / \mathrm{ml} / \mathrm{kg}$ i.p.), placed into a stereotaxic apparatus (Kopf Instruments), and received bilateral microinjections of recombinant adeno-associated viral vectors encoding GFP only (green fluorescent protein), or $\Delta$ JunD (dominant-negative binding partner of $\triangle \mathrm{FosB}$ ) and GFP, into the NAc (coordinates: $\mathrm{AP}+1.5, \mathrm{ML} \pm 1.2$ from bregma; $\mathrm{DV}-7.6$ from skull), in a volume of $1.5 \mu \mathrm{l} /$ hemisphere over 7 min using a Hamilton syringe (Harvard Apparatus). $\Delta$ JunD decreases $\Delta$ FosB-mediated transcription by competitively heterodimerizing with $\Delta$ FosB and hence preventing binding of $\Delta \mathrm{FosB}$ to the AP-1 region within promoter regions of target genes (Winstanley et al., 2007; Pitchers et al., 2010b). Even though $\Delta$ JunD binds with high affinity to $\Delta \mathrm{FosB}$, it is possible that some of the observed effects of $\Delta$ JunD might be mediated by antagonizing other AP-1 proteins. However, it appears that $\Delta \mathrm{FosB}$ is the predominant $\mathrm{AP}-1$ protein expressed under the tested conditions (Pitchers et al., 2010b). Between 3 and 4 weeks later, animals received sexual experience during 4 consecutive mating sessions or remained naive to create 4 groups: sexually naive GFP, sexually experienced GFP, sexually naive $\Delta \mathrm{JunD}$, and sexually experienced $\Delta$ JunD. Sexual experience was comprised of 4 consecutive daily mating session. Animals were tested for CPP and diOlistics. Verification of injection sites was performed as described previously (Pitchers et al., 2010b). NAc sections (coronal; $100 \mu \mathrm{m}$ ) were immune-processed for GFP (1:20,000; rabbit anti-GFP antibody; Invitrogen). Spread of virus was primarily limited to the shell portion of the NAc, with additional spread to the core.

$D 1 R / D 2 R$ antagonists. Male rats were anesthetized with an intraperitoneal injection $(0.1 \mathrm{ml} / \mathrm{kg})$ of ketamine $(87 \mathrm{mg} / \mathrm{ml})$ and xylazine $(13$ $\mathrm{mg} / \mathrm{ml}$ ), and placed into a stereotaxic apparatus (Kopf Instruments). Bilateral 21-gauge guide cannulas (Plastics One) were lowered toward the NAc at AP +1.7, ML \pm 1.2 from bregma; $-6.4 \mathrm{DV}$ from skull and secured with dental acrylic, adhered to three screws set into the skull.
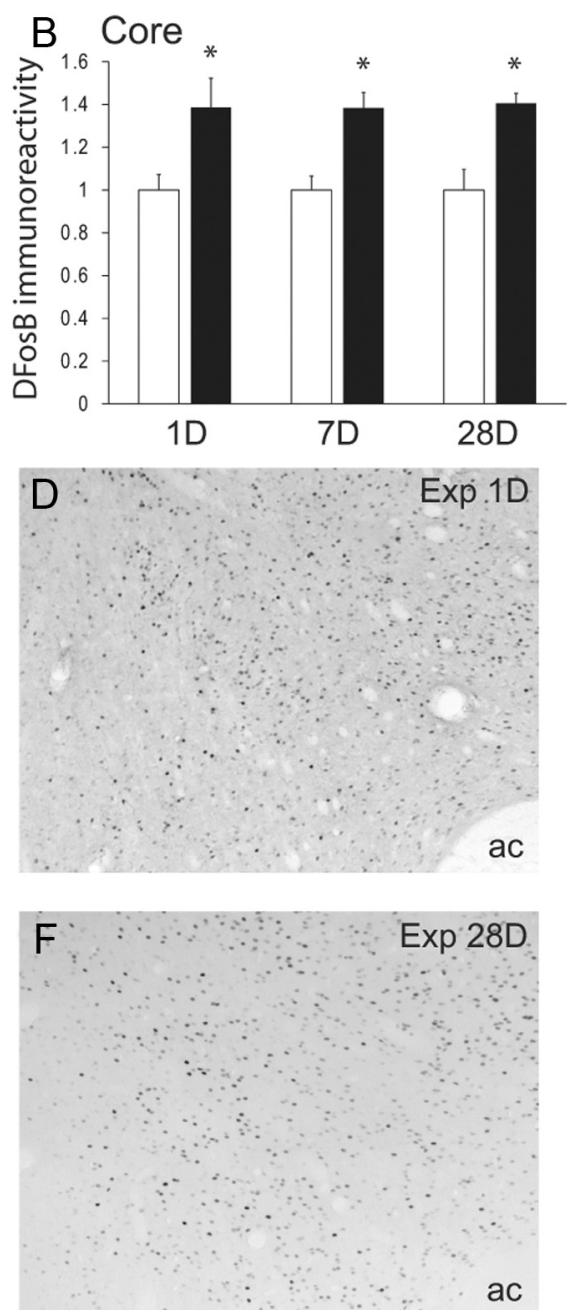

ac

Figure 1. Sexual experience caused an immediate and persistent increase in number of $\Delta$ FosB-IR cells. Fold change of number controls ( $n=4$ each group). Data are group mean \pm SEM. ${ }^{*} p<0.05$, significant difference compared with naive controls. Representative of images of Naive $1 \mathrm{~d}(\boldsymbol{C}), \operatorname{Exp} 1 \mathrm{~d}(\boldsymbol{D}), \operatorname{Exp} 7 \mathrm{~d}(\boldsymbol{E})$, and $\operatorname{Exp} 28 \mathrm{~d}(\boldsymbol{F})$. ac, Anterior commissure. Scale bar, $100 \mu \mathrm{m}$.

Animals were handled daily for habituation to infusion procedures during a 2 week recovery period. Fifteen minutes before the start of each of 4 daily mating sessions by introducing the receptive female, the male rats received bilateral microinjections of D1R antagonist $\mathrm{R}(+) \mathrm{SCH}-23390$ hydrochloride (Sigma-Aldrich), D2 receptor (D2R) antagonist S-(-) eticlopride hydrochloride (Sigma-Aldrich) were dissolved in sterile saline $(0.9 \%$; each at $10 \mu \mathrm{g}$ in $1 \mu \mathrm{l}$ per hemisphere; dissolved in $0.9 \%$ saline), or saline ( $1.0 \mu \mathrm{l}$ per hemisphere), at a flow rate of $1.0 \mu \mathrm{l} / \mathrm{min}$ over a 1 min interval followed by $1 \mathrm{~min}$ with the injection cannula left in place for drug diffusion. The volume of this injection will infuse both core and shell, as infusions of $0.5 \mu \mathrm{l}$ are restricted to shell or core subdivisions (Laviolette et al., 2008). The dosages were based on previous studies showing that these or lower dosages affected drug or natural reward behavior (Laviolette et al., 2008; Roberts et al., 2012). Control males remained sexually naive but received intra-NAc saline before placement in the empty test cage, during 4 daily handling sessions. One week after final mating or handling session, males were tested for Amph $\mathrm{CPP}$, and spine and $\triangle$ FosB analysis. The use of four sessions, rather than five sessions as in the other experiments, was chosen to eliminate excessive damage to the NAc caused by the repeated infusions and thus allow for spine and $\Delta$ FosB analysis. Indeed, damage was not evident, and analyses of spine and $\triangle$ FosB in NAc of saline-infused animals showed similar data as non-infused groups in the previous experiments. Two-way ANOVA and Holm-Sidak method with sig- 


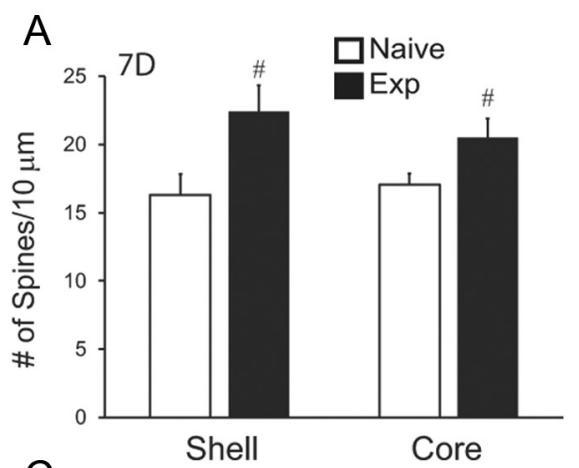

C
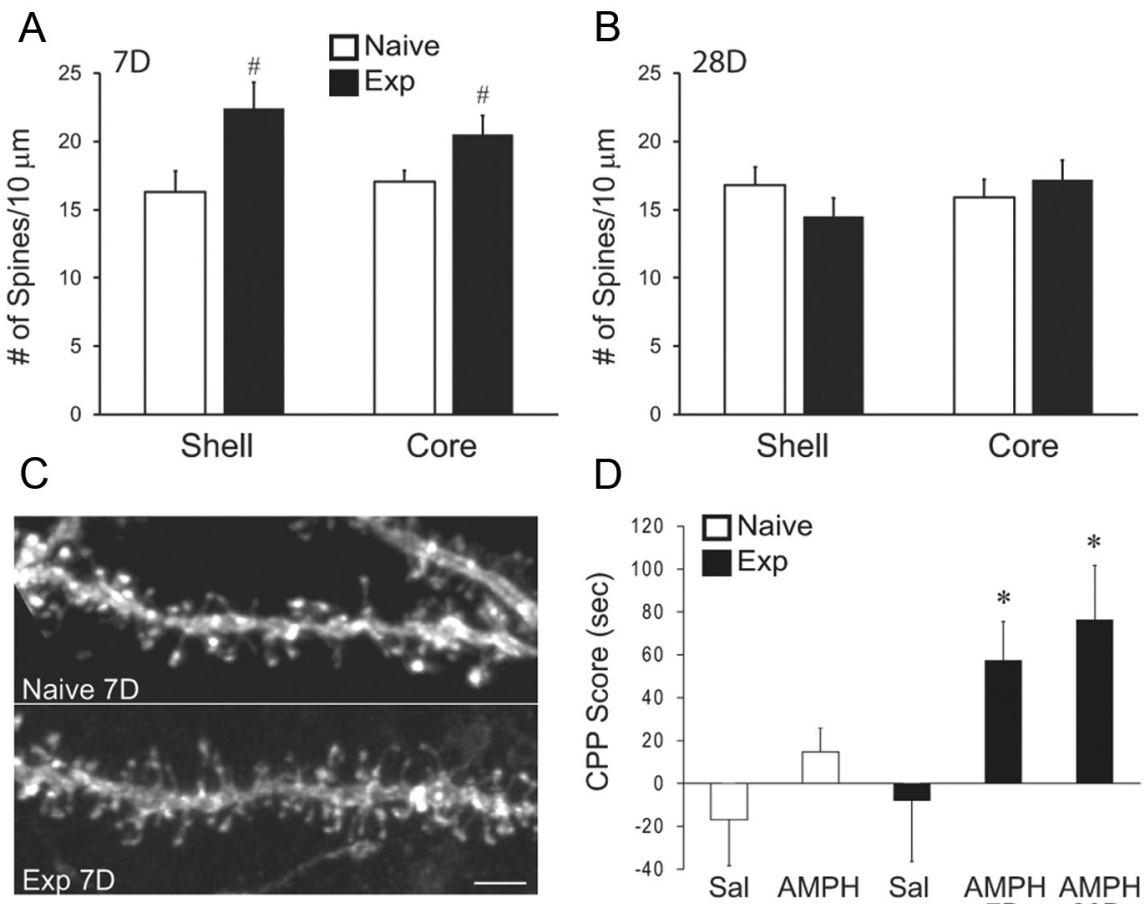

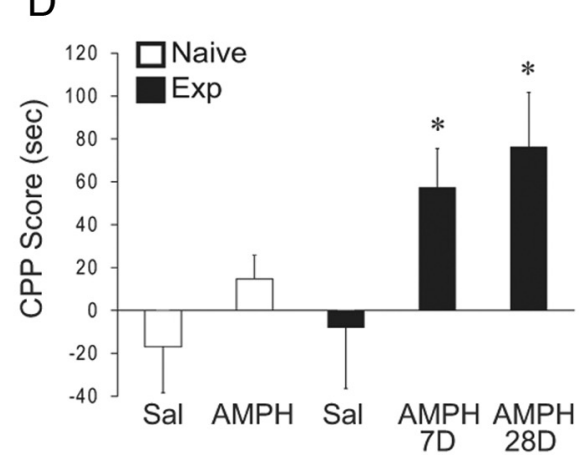

Sex experienced-induced increase in dendritic spines is transient

Pitchers et al. (2010a) previously reported using Golgi impregnation techniques that sexual experience followed by $7 \mathrm{~d}$, but not $1 \mathrm{~d}$, of reward abstinence caused significantly increased dendritic branching and number of dendritic spines on NAc shell and core neurons (Pitchers et al., 2010a). Here, spinogenesis in sexually naive and experienced males was examined either $7 \mathrm{~d}$ or $28 \mathrm{~d}$ after final mating session. The current findings using a diOlistics labeling method confirmed that sexual experience followed by a $7 \mathrm{~d}$ sex abstinence period increased the numbers of dendritic spines $\left(F_{(1,8)}=9.616, p=0.015\right.$; Fig. $\left.2 A-C\right)$. Specifically, the number of dendritic spines was significantly increased in the NAc shell and core (Fig. 2A: shell, $p=$ 0.011 ; core, $p=0.044)$. However, this increased spine density was transient and no longer detected after a prolonged sex abstinence period of $28 \mathrm{~d}$ in either NAc subregion (Fig. 2B).

Figure 2. Sexual experience caused an increase in number of dendritic spines in the NAc and sensitized Amph reward. $A, B$, The number of dendritic spines in the NAc shell and core of $7 \mathrm{~d}(\boldsymbol{A})$ or $28 \mathrm{~d}$ (DB of sexually naive [white] and experienced [black] animals; $n=4$ or 5). Data are group mean \pm SEM. ${ }^{*} p<0.05$, significant difference compared with naive controls. C, Representative dendritic segments from Naive $7 \mathrm{~d}$ and Exp $7 \mathrm{~d}$ groups used to quantify spine density. Scale bar, $3 \mu \mathrm{m}$. D, The amount of time spent in the paired chamber (Amph or saline) during the post-test minus the pretest (CPP score) for sexually naive (white) or experienced (black) animals tested either $7 \mathrm{~d}$ or $28 \mathrm{~d}$ after final mating or handling session: Naive-Sal ( $7 \mathrm{~d}$ after handling; $n=8$ ), Naive Amph ( $7 \mathrm{~d}$ after handling; $n=9$ ), Exp-Sal (combined groups of animals tested either $7 \mathrm{~d}$ or $28 \mathrm{~d}$ after mating; $n=7$ ), $7 \mathrm{~d}$ Exp Amph (7 $\mathrm{d}$ after mating; $n=9$ ), and $28 \mathrm{~d}$ Exp Amph (28d after mating; $n=11)$. Sal groups received Sal paired with both chambers. ${ }^{*} p<$ 0.05 , significant difference compared with sexually experienced saline controls.

nificance set at $p<0.05$ was used to determine sex experienceinduced facilitation of sexual behavior.

\section{Results}

Sex experienced-induced $\Delta$ FosB upregulation is long-lasting First, the temporal correlations between sex experiencedinduced changes in $\triangle \mathrm{FosB}$ expression, dendritic spines in the NAc, and Amph-CPP were determined, specifically after short and prolonged periods of abstinence from sexual reward (7 or $28 \mathrm{~d})$. Previously, it was demonstrated that sexual experience of 5 daily mating sessions caused an accumulation of $\Delta$ FosB throughout the mesolimbic system, notably in the NAc (Wallace et al., 2008; Pitchers et al., 2010b). In these past studies, $\Delta$ FosB levels were measured within $1 \mathrm{~d}$ after sexual behavior, and it was not known whether $\Delta$ FosB accumulation persisted after prolonged periods of reward abstinence. Sexually experienced males were perfused 1,7 , or $28 \mathrm{~d}$ after the final of 5 daily mating sessions, during which the males mated to one ejaculation. Sexually naive controls were perfused at the same time point after the final of 5 daily handling sessions. Numbers of $\Delta$ FosB-IR cells in the NAc shell and core were significantly higher than sexually naive controls at all time points (Fig. $1 A$, shell; $1 \mathrm{~d}, p=0.022 ; 7 \mathrm{~d}, p=0.015$; Fig. $1 B$ : core; $1 \mathrm{~d}, p=0.024 ; 7 \mathrm{~d}, p<0.001 ; 28 \mathrm{~d}, p<0.001)$, except in the NAc shell after $28 \mathrm{~d}$ abstinence $(p=0.280)$. Thus, $\Delta$ FosB upregulation persists during abstinence after sexual experience for a period of at least $28 \mathrm{~d}$.

\section{Sex experienced-induced sensitized Amph reward is long-lasting}

We previously demonstrated that sexual experience followed by 7-10 d of abstinence resulted in enhanced Amph reward (Pitchers et al., 2010a). Specifically, sexually experienced animals formed a significant conditioned place preference (CPP) for lower doses of Amph (0.5 or $1.0 \mathrm{mg}$ / $\mathrm{kg}$ ) that did not induce CPP in sexually naive controls. The current study confirmed and extended these previous results by demonstrating enhanced Amph reward in sexually experienced animals both after a $7 \mathrm{~d}$ as well as a $28 \mathrm{~d}$ sex abstinence period (Fig. $2 D ; F_{(2,24)}=4.971, p=0.016$ ). Specifically, sexually experienced animals with either 7 or $28 \mathrm{~d}$ abstinence period spent significantly greater time in the Amph-paired chamber during the post-test compared with sexually experienced negative controls that received saline in the both chambers (Fig. 2D: Exp-Sal vs $7 \mathrm{~d} \operatorname{Exp} \mathrm{AMPH}, p=0.032$; vs $28 \mathrm{~d} \operatorname{Exp} \mathrm{AMPH}, p=0.021$ ). Confirming previous findings, sexually naive animals did not spend more time in the Amph-paired chamber during the posttest and did not differ in preference from the sexually naive saline control group (Fig. 2D) (Pitchers et al., 2010a).

\section{$\Delta$ FosB activity is critical for sex experience-induced sensitized Amph reward}

The results thus far demonstrate that sexual experience caused long-lasting accumulation of $\Delta$ FosB in NAc neurons correlated with enhanced Amph reward. To determine whether increased $\Delta$ FosB activity is critical for enhanced Amph reward, $\Delta \mathrm{JunD}$, a dominant-negative binding partner of $\Delta$ FosB that suppresses $\Delta$ FosB-mediated transcription (Winstanley et al., 2007), was overexpressed via viral vector-mediated gene transfer in the NAc (Fig. $3 A, B$ ). Results of the Amph CPP tests showed that attenuation of $\Delta$ FosB activity by expressing $\Delta$ JunD in the NAc prevented the effects of sexual experience and $7 \mathrm{~d}$ sex reward 

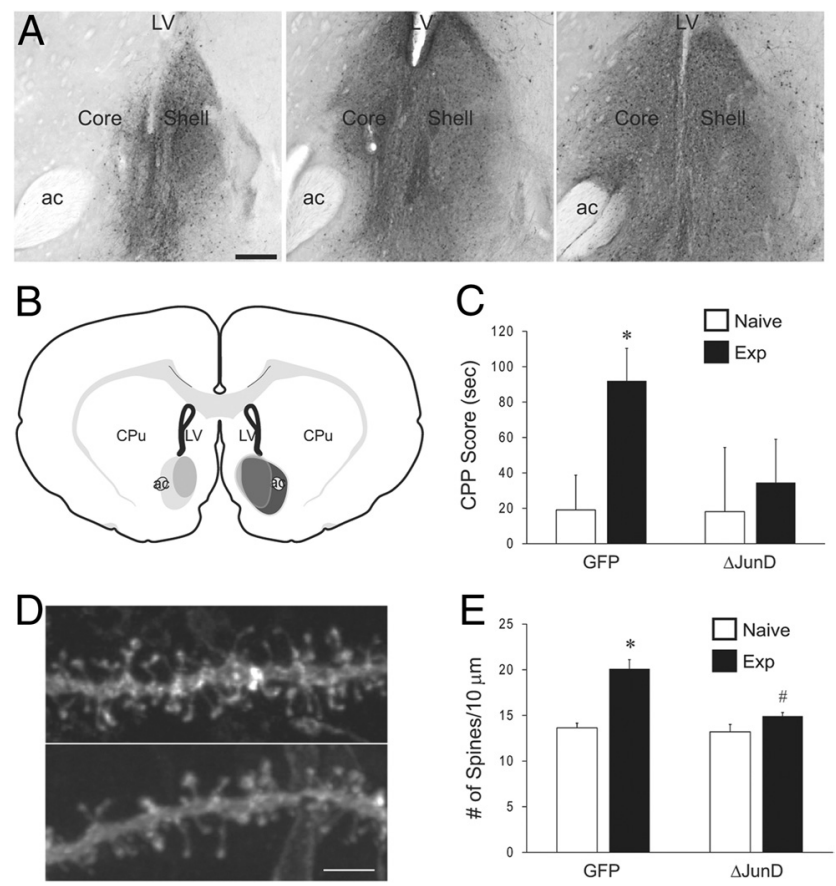

Figure 3. Attenuating $\triangle$ FosB activity in the NAc blocked sensitized AMPH reward and increase in number of NAc spines in sexually experienced animals. $\boldsymbol{A}$, Representative images of GFP expression in three animals receiving an injection of recombinant adeno-associated viral$\Delta$ JunD directed at the nucleus accumbens, illustrating small (left), intermediate (middle), and large (right) injection sites. ac, Anterior commissure; LV, lateral ventricle. Scale bar, $250 \mu \mathrm{m}$. $\boldsymbol{B}$, Schematic illustration of most prominent locations and patterns of spread of virus. In all animals, GFP was detected in the shell, but spread to the core was variable. $\boldsymbol{C}$, The amount of time spent in the Amph-paired chamber during the post-test minus the pretest (CPP score) for sexually naive (white) and experienced (black) animals that either received an injection of GFP control vector (Naive, $n=9$; $\operatorname{Exp}, n=10$ ) or $\Delta$ JunD vector (Naive, $n=9$; $\operatorname{Exp}, n=9$ ). $\boldsymbol{D}$, Representative images of dendritic segments from sexually experienced GFP and $\Delta$ JunD used to quantify spine density. Scale bar, $3 \mu \mathrm{m}$. $\boldsymbol{E}$, The number of dendritic spines in the NAc of sexually naive (white) and experienced (black) animals that either received an injection of GFP control vector or $\Delta$ JunD vector. Data are group mean \pm SEM. ${ }^{*} p<0.05$, significant difference compared with naive controls. ${ }^{\#} p<0.05$, significant difference from GFP experienced controls.

abstinence on enhanced Amph reward. Sexually experienced $\Delta$ JunD animals did not form a significant CPP for Amph and did not differ from sexually naive $\Delta$ JunD animals (Fig. $3 B$ ). In contrast, sexually experienced GFP control animals formed a CPP for Amph as indicated by a significantly greater CPP score compared with sexually naive GFP controls (Fig. $3 B, p=0.018$ ).

The attenuating effects of $\Delta \mathrm{JunD}$ overexpression were not the result of a disruption of sexual behavior during the acquisition of sexual experience. Expression of $\Delta$ JunD in the NAc has previously been shown to prevent the facilitation of sexual behavior after sexual experience (Pitchers et al., 2010b). Indeed, this was confirmed in the current experiment. GFP control animals displayed shorter latencies to mount, intromission, and ejaculation, and fewer mounts and intromission during the fourth consecutive day of mating tests, compared with the first day of mating (Table 1). In contrast, $\Delta$ JunD-injected animals did not display significantly shorter latencies to mount or intromission or lower numbers of mounts during the fourth day of mating compared with the first. Thus, $\Delta$ JunD infusions into the NAc attenuated the effects of sexual experience. However, there were no significant differences in any of the mating parameters between GFP control and $\Delta$ JunD-infused groups during any of the mating tests, indicating that effects of $\Delta$ JunD infusions on sex experience-induced sensitization of Amph CPP are not the result of differences in mating experience per se (Table 1 ).

\section{$\Delta$ FosB is critical for sex experience-induced increase in NAc dendritic spines}

$\Delta$ FosB activity was also required for the increased spine density of NAc neurons after sex experience and $7 \mathrm{~d}$ sex reward abstinence (Fig. 3C,D). For spine analysis in the NAc of animals described above for CPP, two-way ANOVA showed significant effects of both sexual experience $\left(F_{(1,34)}=31.768, p<0.001\right)$ and viral vector treatment $\left(F_{(1,34)}=14.969, p=0.001\right)$, as well as an interaction $\left(F_{(1,34)}=10.651, p=0.005\right)$. Specifically, sexually experienced GFP control animals had a greater number of NAc spines compared with sexually naive GFP controls (Fig. 3D: $p<0.001$ ), confirming our previous finding (Pitchers et al., 2010a). In contrast, sexually experienced $\Delta \mathrm{JunD}$ animals were not significantly different from sexually naive $\Delta$ JunD groups, and were significantly lower compared with sexually experienced GFP control animals (Fig. $3 D: p<0.001$ ). Thus, $\Delta$ JunD expression in the NAc blocked the effects of sexual experience and reward abstinence on NAc spinogenesis.

\section{D1R antagonist blocks sex experience-induced $\Delta$ FosB upregulation}

To determine whether D1R or D2R activation in the NAc during mating is required for sex experience-induced $\Delta$ FosB upregulation and sensitized Amph CPP, animals received local infusions of either a D1R or D2R antagonist (or saline) into the NAc 15 min before each of 4 daily consecutive mating sessions. Importantly, neither D1R nor D2R antagonist infusions into the NAc affected initiation or expression of sexual behavior during any of the mating sessions (Fig. 4D-F). Likewise, D1R or D2R antagonism did not prevent facilitative effects of sexual experience on mating, as all groups demonstrated facilitation of sexual behavior, evidenced by shorter ejaculation latencies on day 4 compared with day 1 (Fig. $4 F)\left(F_{(1,40)}=37.113, p<0.001\right.$; Sal, $p=0.004$; D1R Ant, $p=0.007$; D2R Ant, $p<0.001)$.

Analysis of the number of $\Delta$ FosB-IR cells in the NAc $7 \mathrm{~d}$ after the last NAc infusion and mating or handling session revealed significant differences between groups in both NAc shell $\left(F_{(3,29)}=\right.$ $18.070, p<0.001)$ and core $\left(F_{(3,29)}=10.017, p<0.001\right)$. First, sexual experience in saline-infused controls caused a significant upregulation of $\Delta$ FosB compared with sexually naive controls (Fig. $5 A$, shell $p<0.001$; Fig. $5 B$ : core, $p<0.001$ ), confirming results above. Antagonism of D1R, but not D2R, prevented or attenuated this upregulation of $\Delta$ FosB. In the NAc shell, D1R antagonist treated sexually experienced males showed no increase in $\Delta$ FosB-IR cells compared with sexually naive controls (Fig. 5A: $p=0.110$ ), and $\Delta$ FosB expression was significantly lower compared with sexually experienced saline males (Fig. $5 A: p=0.002$ ). In the NAc core, D1R antagonism had a partial effect: $\triangle$ FosB was significantly increased in $\mathrm{D} 1 \mathrm{R}$ antagonist-treated males compared with naive saline controls (Fig. $5 B: p=0.031$ ), but this upregulation was significantly lower compared with sexually experienced saline treated males (Fig. 5B: $p=0.012$ ). D2R antagonist treatment did not affect $\Delta$ FosB induction as sexually experienced males that received D2R antagonist had a significantly greater number of $\Delta$ FosB-IR cells compared with naive saline controls (Fig. 5A: shell, $p<0.001$; Fig. 5B: core, $p<0.001$ ) and D1R antagonist-treated males (Fig. $5 A$ : shell, $p<0.001$; Fig. $5 B$ : core, $p=0.013$ ), and did not differ from sexually experienced saline males.

To control for potential spread of D1R or D2R antagonists into the dorsal striatum, $\Delta$ FosB expression was analyzed in an 
Table 1. Parameters of sexual behavior during acquisition of sexual experience in groups that received NAc infusions of GFP- or $\Delta$ JunD-expressing viral vectors $^{a}$

\begin{tabular}{|c|c|c|c|c|}
\hline & \multicolumn{2}{|l|}{ GFP } & \multicolumn{2}{|l|}{$\Delta$ JunD } \\
\hline & Day 1 & Day 4 & Day 1 & Day 4 \\
\hline Mount latency (s) & $594.56 \pm 216.34$ & $84 \pm 20.96^{*}$ & $528 \pm 217.68$ & $159.22 \pm 58.43$ \\
\hline Intromission latency (s) & $780.22 \pm 246.77$ & $99.11 \pm 32.45^{*}$ & $539.67 \pm 216.04$ & $163.89 \pm 57.57$ \\
\hline Ejaculation latency (s) & $1177.33 \pm 200.45$ & $593.56 \pm 143.01^{*}$ & $1390.38 \pm 175.79$ & $645.56 \pm 140.7^{*}$ \\
\hline Mounts (no.) & $8.75 \pm 2.96$ & $5 \pm 2.12^{*}$ & $8.5 \pm 1.95$ & $9.4 \pm 4.1$ \\
\hline
\end{tabular}

${ }^{a}$ Data are shown for day 1 and the last day of four daily consecutive mating sessions (day 4).

*Significant differences from day 1 in the same treatment group. No differences between GFP or $\Delta$ JunD groups were detected on either day 1 or day 4.

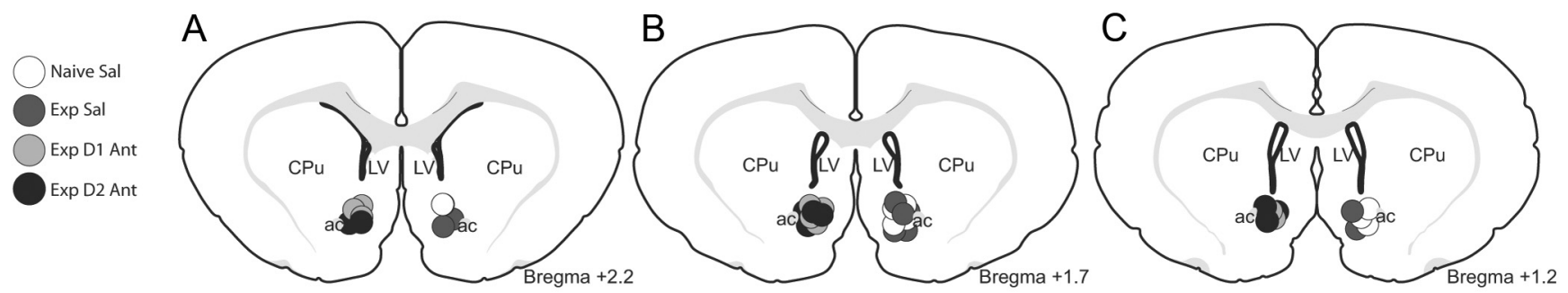

D

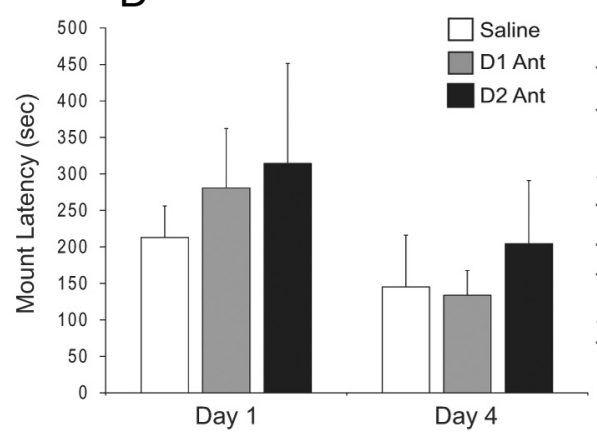

E

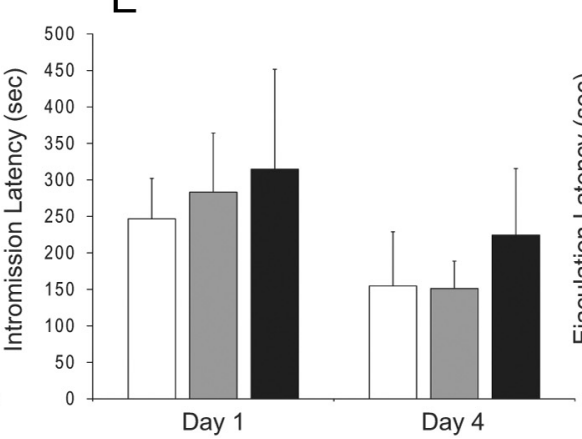

F

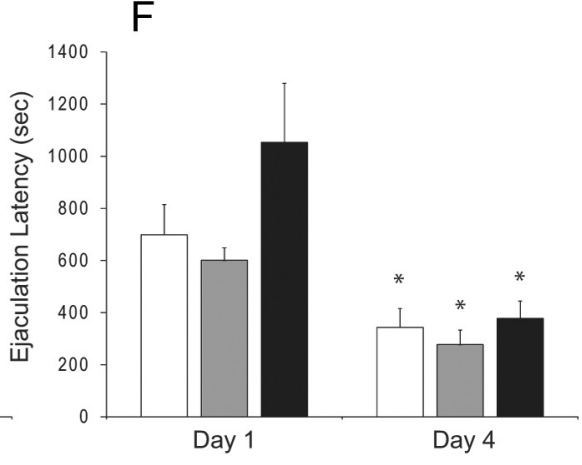

Figure 4. Dopamine receptor antagonists infused into the NAc did not affect sexual behavior. Coronal NAc sections $(\boldsymbol{A},+2.2 ; \boldsymbol{B},+1.7 ; \boldsymbol{C},+1.2$ from bregma) indicating intra-NAc injection sites for all animals. Cannulas were bilateral but are represented unilaterally for ease of presentation of all animals (Naive-Sal, white, $n=7 ;$ Exp-Saline; dark gray, $n=9 ;$ Exp D1R Ant, light gray, $n=$ 9; Exp D2R Ant, black, $n=8$ ). ac, Anterior commissure; LV, lateral ventricle; (Pu, caudate-putamen. Mount latency $(\boldsymbol{D})$, intromission latency $(\boldsymbol{E})$, and ejaculation latency $(\boldsymbol{F})$ for all sexually experienced groups (Saline, white; D1R Ant, gray; D2R Ant, black). Data represent mean \pm SEM. ${ }^{*} p<0.05$, significant difference between day 1 and day 4 within treatment.

area immediately dorsal to the NAc and adjacent to the lateral ventricle, as induction of $\Delta$ FosB in the dorsal striatum by psychostimulants and opiates is dependent on D1R activity (Zhang et al., 2002; Muller and Unterwald, 2005). Sexual experience increased the numbers of $\Delta$ FosB-ir cells in the dorsal striatum in salinetreated males (Naive-Sal: $35.6 \pm 4.8$ vs Exp-Sal: $82.9 \pm 5.1 ; p<$ 0.001 ), confirming our previous report (Pitchers et al., 2010b). Moreover, neither D1R nor D2R antagonist infusions into the NAc affected sex experience-induced $\Delta$ FosB in the dorsal striatum (Exp-D1R: $82.75 \pm 2.64$ ir cells; Exp-D2R: $83.9 \pm 4.4$ ir cells; $p<0.001$ compared with Naive-Sal controls). These findings suggest that spread of antagonist infusions was primarily limited to the NAc.

\section{D1R antagonist in NAc blocks sensitized Amph reward}

D1R blockade in NAc during mating also blocked sex experienceinduced enhanced Amph reward, tested $7 \mathrm{~d}$ after the last NAc infusion and mating test $\left(F_{(3,29)}=2.956, p=0.049\right)$. Sexually experienced animals that received saline in the NAc during mating sessions spent a significantly greater amount of time in the Amph-paired chamber compared with sexually naive males (Fig. $6 A, p=0.025)$, confirming results above. In contrast, sexually experienced animals that received intra-NAc D1R antagonist during mating did not form a CPP for Amph. They did not differ from sexually naive controls, and spent significantly less time in the Amph-paired chamber compared with saline (Fig. $6 A: p=$ 0.049 ) or D2R antagonist (Fig. $6 A: p=0.038$ ) infused sexually experienced males. D2R antagonist infusions did not affect the enhanced Amph reward as sexually experienced animals with NAc D2R antagonist infusions formed a significant Amph-CPP compared with naive saline controls (Fig. 6A: $p=0.040$ ) and D1R antagonist experienced animals (Fig. $6 A: p=0.038$ ), and did not differ from sexually experienced saline males.

\section{D1R antagonist treatment blocks sex experience-induced NAc spinogenesis}

Analysis of spine density in the NAc of these same animals showed that D1R activation during mating was required for increased NAc spine density after sexual experience and $7 \mathrm{~d}$ of sex reward abstinence (Fig. $6 B ; F_{(3,26)}=41.558, p<0.001$ ). Specifically, sexually experienced saline controls and D2R antagonist animals had a significantly greater number of spines compared with sexually naive saline controls (Fig. 6B: $p<0.001$ ) confirming our previous findings (Pitchers et al., 2010a) and findings with GFP control viral vectors described above. In contrast, sexually experienced D1R antagonist-infused animals did not differ from sexually naive saline-infused controls (Fig. 6B). There was a partial effect of D2R antagonist infusion as D2R infused animals showed significantly lower spine densities than sexually experienced saline controls (Fig. $6 B: p=0.02$ ), but significantly higher 
numbers of spines compared to sexually naive saline controls and D1R-treated experienced males ( $p<0.001$; Fig. $6 B)$. Thus, D1R blockade in the NAc during mating blocked the effects of sexual experience and reward abstinence on NAc spinogenesis.

\section{Discussion}

In the current study, we demonstrated cross-sensitization between natural and drug reward, when the natural reward is followed by a period of abstinence. Specifically, we showed that experience with sexual behavior, followed by 7 or $28 \mathrm{~d}$ of abstinence, causes enhanced Amph reward. These findings have similarities with the established critical role of an abstinence period from drugs of abuse in the incubation of drug craving ( $\mathrm{Lu}$ et al., 2005; Thomas et al., 2008; Wolf, 2010b, 2012; Xue et al., 2012). Furthermore, natural reward-induced $\triangle \mathrm{FosB}$ in the NAc is critical for cross-sensitizing effects of natural reward abstinence on psychostimulant reward, potentially via spinogenesis in the NAc during a period of reward abstinence. We demonstrated that $\Delta \mathrm{FosB}$ accumulation in the NAc after sexual experience is long-lasting and dependent on NAc D1R activity during mating. In turn, this D1R-mediated $\Delta$ FosB upregulation in the NAc was shown to be critical for enhanced reward for Amph and increased spine density in the NAc, even though these outcomes of sexual experience are dependent on a period of abstinence from sexual reward (Pitchers et al., 2010a). Finally, we showed that NAc spinogenesis may contribute to the initial development of short-term expression of sensitized Amph reward but is not critical for continued expression of enhanced drug reward, as increased spine density in NAc was transient and observed after a $7 \mathrm{~d}$, but not $28 \mathrm{~d}$, abstinence period.

It has long been known that dopamine is released in the NAc during natural reward behavior, including sexual behavior. Upon introduction of a receptive female, extracellular dopamine in the NAc is increased and remains elevated during mating (Fiorino et al., 1997). The current study showed that infusing dopamine receptor antagonists into the NAc during mating did not have an effect on the initiation or performance of sexual behavior, which is consistent with the notion that dopamine is not involved in the expression of reward behavior per se, but rather for attribution of incentive salience of sex-related cues (Berridge and Robinson, 1998). Indeed, cues predictive of sexual reward cause activation of neurons within the mesolimbic dopamine reward system, including the dopaminergic cells in the ventral tegmental area and their target, the NAc (Balfour et al., 2004). Repeated sexual behavior induces $\triangle \mathrm{FosB}$ in the NAc, which in turn mediates the experience-induced reinforcement of sexual behavior (Pitchers et al., 2010b). Current results show that mating-induced $\Delta$ FosB upregulation is, indeed, dependent on D1R activation in the NAc
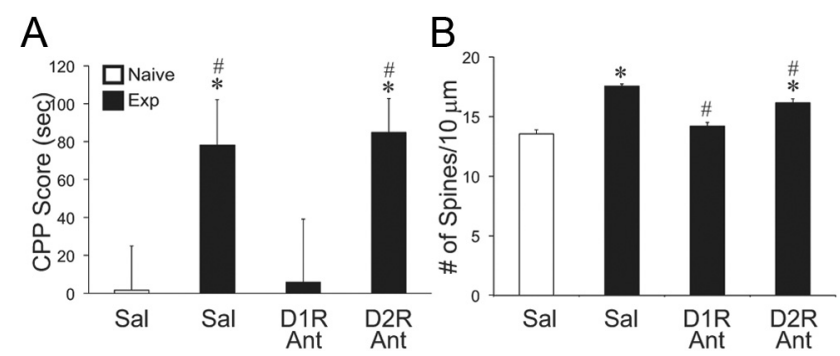

Figure 6. Blocking D1 receptors in the NAc abolishes sensitized Amph reward and increased dendritic spines in sexually experienced animals. $\boldsymbol{A}$, The amount of time spent in the Amphpaired chamber during the post-test minus the pretest (CPP score, seconds) for sexually naive (white, $n=6$ ) and experienced (black) animals that received saline $(n=7)$, D1R antagonist $(n=9)$, or D2R antagonist $(n=8)$. Data are group mean \pm SEM. ${ }^{*} p<0.05$, significant difference compared with naive saline controls. ${ }^{\#} p<0.05$, significant difference from D1R Ant experienced animals. $\boldsymbol{B}$, The number of dendritic spines (per $10 \mu \mathrm{m}$ ) for sexually naive (white, $n=7)$ and experienced (black) animals that received saline ( $n=8)$, D1R antagonist $(n=8)$, or D2R antagonist $(n=8)$. Data are group mean \pm SEM. ${ }^{*} p<0.05$, significant difference compared with naive saline controls. ${ }^{\#} p<0.05$, significant difference from experienced saline controls. 
during mating. This finding is consistent with previous studies showing that repeated psychostimulant administration persistently increased $\Delta$ FosB in NAc medium spiny neurons expressing D1R (Lee et al., 2006; Kim et al., 2009) and that such $\Delta$ FosB upregulation is dependent on D1R activition (Zhang et al., 2002). In addition, sensitized drug responses, normally observed in a drug experienced animal, can be produced in the absence of prior drug exposure by the overexpression of $\Delta$ FosB in D1R expressing neurons in the striatum (Kelz et al., 1999). Thus, both natural and drug rewards increase $\Delta \mathrm{FosB}$ in the NAc via a D1R-dependent mechanism to sensitize reward behaviors.

Moreover, the current findings demonstrate that $\Delta \mathrm{FosB}$ is a critical mediator of the cross-sensitization between natural reward experience and psychostimulant reward. As noted, $\Delta$ FosB activity in the NAc has previously been implicated in sensitized drug responses, as $\Delta$ FosB overexpression in the NAc sensitizes the locomotor activation to cocaine after prior acute or repeated administration (Kelz et al., 1999), increases sensitivity to cocaine and morphine CPP (Kelz et al., 1999; Zachariou et al., 2006), and causes self-administration of lower doses of cocaine (Colby et al., 2003). The current study shows that blockade of D1R or $\Delta$ FosB activity in the NAc during mating abolished sex experienceinduced sensitization of Amph reward. Thus, natural and drug rewards not only converge on the same neural pathway, they converge on the same molecular mediators (Nestler et al., 2001; Wallace et al., 2008; Hedges et al., 2009; Pitchers et al., 2010b), and likely in the same neurons in the NAc (Frohmader et al., 2010b), to influence the incentive salience and the "wanting" of both types of rewards (Berridge and Robinson, 1998).

The current study demonstrated that an abstinence period from sexual reward is required for the sensitization of Amph reward and NAc spinogenesis. We hypothesize that $\Delta$ FosB during this abstinence period affects neuronal function by altering downstream gene expression to initiate spinogenesis and alter synaptic strength. Indeed, blocking the induction of $\Delta \mathrm{FosB}$ in the NAc during mating prevented increased spine density in the NAc detected after reward abstinence. Moreover, infusion of a D1R antagonist into the NAc before each mating session prevented the sex experience-induced increase in $\Delta$ FosB and the subsequent increased spine density. $\Delta$ FosB is a transcription factor that can act as a transcriptional activator or repressor to influence the expression of a myriad of target genes that may in turn influence spine density and synaptic strength in the NAc (Nestler, 2008). More specifically, $\Delta$ FosB activates cyclic-dependent kinase-5 (Bibb et al., 2001; Kumar et al., 2005), nuclear factor $\kappa$ B (NF- $\kappa$ B) (Russo et al., 2009b), and the GluA2 subunit of the glutamate AMPA receptor (Vialou et al., 2010) and represses transcription of the immediate early gene c-fos (Pitchers et al., 2010b) and histone methyltransferase G9 (Maze et al., 2010). Cyclicdependent kinase-5 regulates cytoskeletal proteins and neurite outgrowth (Taylor et al., 2007). Moreover, activating NF- $\kappa$ B increases the number of dendritic spines in the NAc, whereas inhibition of NF- $\kappa \mathrm{B}$ decreased basal dendritic spines and blocks the cocaine-induced increase in spines (Russo et al., 2009b). Hence, sexual reward increases $\Delta$ FosB in the NAc, which may alter NAc spine density through multiple targets (i.e., cyclic-dependent kinase-5, NF- $\kappa \mathrm{B}$ ) and that the overall consequence is sensitized drug reward, as was hypothesized by Russo et al. (2009a) for the actions of repeated cocaine.

An unexpected observation in the current study was that increased spine density in the NAc was transient, and no longer detected at $28 \mathrm{~d}$ after sexual experience. Thus, increased spine density was correlated with the onset of enhanced Amph reward and may contribute to the initial development or short-term expression of sensitized Amph responses. However, increased spine density was not required for the persistence of sensitized Amph reward after prolonged abstinence periods. We have previously shown that sexual experience causes a short-term (7, but not 28, days after last mating) increase of NMDA receptor subunit NR-1 in the NAc, which reverted to baseline levels after prolonged periods of reward abstinence (Pitchers et al., 2012). This increased NMDA receptor expression was hypothesized to be indicative of sex experienced-induced silent synapses (Huang et al., 2009; Brown et al., 2011; Pitchers et al., 2012), and suggestive of the possibility that sex experience-induced spine growth is dependent on enhanced NMDA receptor activity (Hamilton et al., 2012).

In conclusion, the current study highlights the crosssensitization of drug reward by a natural reward (sex) and its dependence on a reward abstinence period. Moreover, this behavioral plasticity was mediated by $\Delta$ FosB via D1R activation in the NAc. Therefore, data suggest that loss of a natural reward after reward experience may make individuals vulnerable to development of drug addiction and that one mediator of this increased vulnerability is $\Delta$ FosB and its downstream transcriptional targets.

\section{References}

Balfour ME, Yu L, Coolen LM (2004) Sexual behavior and sex-associated environmental cues activate the mesolimbic system in male rats. Neuropsychopharmacology 29:718-730. CrossRef Medline

Berridge KC, Robinson TE (1998) What is the role of dopamine in reward: hedonic impact, reward learning, or incentive salience? Brain Res Brain Res Rev 28:309-369. CrossRef Medline

Bibb JA, Chen J, Taylor JR, Svenningsson P, Nishi A, Snyder GL, Yan Z, Sagawa ZK, Ouimet CC, Nairn AC, Nestler EJ, Greengard P (2001) Effects of chronic exposure to cocaine are regulated by the neuronal protein Cdk5. Nature 410:376-380. CrossRef Medline

Bradley KC, Meisel RL (2001) Sexual behavior induction of c-Fos in the nucleus accumbens and amphetamine-stimulated locomotor activity are sensitized by previous sexual experience in female Syrian hamsters. J Neurosci 21:2123-2130. Medline

Brown TE, Lee BR, Mu P, Ferguson D, Dietz D, Ohnishi YN, Lin Y, Suska A, Ishikawa M, Huang YH, Shen H, Kalivas PW, Sorg BA, Zukin RS, Nestler EJ, Dong Y, Schlüter OM (2011) A silent synapse-based mechanism for cocaine-induced locomotor sensitization. J Neurosci 31:8163-8174. CrossRef Medline

Cameron CM, Carelli RM (2012) Cocaine abstinence alters nucleus accumbens firing dynamics during goal-directed behaviors for cocaine and sucrose. Eur J Neurosci 35:940-951. CrossRef Medline

Chen BT, Hopf FW, Bonci A (2010) Synaptic plasticity in the mesolimbic system: therapeutic implications for substance abuse. Ann N Y Acad Sci 1187:129-139. CrossRef Medline

Colby CR, Whisler K, Steffen C, Nestler EJ, Self DW (2003) Striatal cell type-specific overexpression of $\Delta \mathrm{FosB}$ enhances incentive for cocaine. J Neurosci 23:2488-2493. Medline

Fiorino DF, Coury A, Phillips AG (1997) Dynamic changes in nucleus accumbens dopamine efflux during the Coolidge effect in male rats. J Neurosci 17:4849-4855. Medline

Forlano PM, Woolley CS (2010) Quantitative analysis of pre- and postsynaptic sex differences in the nucleus accumbens. J Comp Neurol 518:1330 1348. CrossRef Medline

Frohmader KS, Pitchers KK, Balfour ME, Coolen LM (2010a) Mixing pleasures: review of the effects of drugs on sex behavior in humans and animal models. Horm Behav 58:149-162. CrossRef Medline

Frohmader KS, Wiskerke J, Wise RA, Lehman MN, Coolen LM (2010b) Methamphetamine acts on subpopulations of neurons regulating sexual behavior in male rats. Neuroscience 166:771-784. CrossRef Medline

Hamilton AM, Oh WC, Vega-Ramirez H, Stein IS, Hell JW, Patrick GN, Zito $\mathrm{K}$ (2012) Activity-dependent growth of new dendritic spines is regulated by the proteasome. Neuron 74:1023-1030. CrossRef Medline

Hedges VL, Chakravarty S, Nestler EJ, Meisel RL (2009) $\Delta$ FosB overexpres- 
sion in the nucleus accumbens enhances sexual reward in female Syrian hamsters. Genes Brain Behav 8:442-449. CrossRef Medline

Huang YH, Lin Y, Mu P, Lee BR, Brown TE, Wayman G, Marie H, Liu W, Yan Z, Sorg BA, Schlüter OM, Zukin RS, Dong Y (2009) In vivo cocaine experience generates silent synapses. Neuron 63:40-47. CrossRef Medline

Hyman SE, Malenka RC, Nestler EJ (2006) Neural mechanisms of addiction: the role of reward-related learning and memory. Annu Rev Neurosci 29:565-598. CrossRef Medline

Kalivas PW (2009) The glutamate homeostasis hypothesis of addiction. Nat Rev Neurosci 10:561-572. CrossRef Medline

Kauer JA, Malenka RC (2007) Synaptic plasticity and addiction. Nat Rev Neurosci 8:844-858. CrossRef Medline

Kelley AE (2004) Memory and addiction: shared neural circuitry and molecular mechanisms. Neuron 44:161-179. CrossRef Medline

Kelz MB, Chen J, Carlezon WA Jr, Whisler K, Gilden L, Beckmann AM, Steffen C, Zhang YJ, Marotti L, Self DW, Tkatch T, Baranauskas G, Surmeier DJ, Neve RL, Duman RS, Picciotto MR, Nestler EJ (1999) Expression of the transcription factor $\Delta \mathrm{FosB}$ in the brain controls sensitivity to cocaine. Nature 401:272-276. CrossRef Medline

Kim Y, Teylan MA, Baron M, Sands A, Nairn AC, Greengard P (2009) Methylphenidate-induced dendritic spine formation and $\triangle \mathrm{FosB}$ expression in nucleus accumbens. Proc Natl Acad Sci U S A 106:2915-2920. CrossRef Medline

Koob GF, Volkow ND (2010) Neurocircuitry of addiction. Neuropsychopharmacology 35:217-238. CrossRef Medline

Kumar A, Choi KH, Renthal W, Tsankova NM, Theobald DE, Truong HT, Russo SJ, Laplant Q, Sasaki TS, Whistler KN, Neve RL, Self DW, Nestler EJ (2005) Chromatin remodeling is a key mechanism underlying cocaineinduced plasticity in striatum. Neuron 48:303-314. CrossRef Medline

Laviolette SR, Lauzon NM, Bishop SF, Sun N, Tan H (2008) Dopamine signaling through D1-like versus D2-like receptors in the nucleus accumbens core versus shell differentially modulates nicotine reward sensitivity. J Neurosci 28:8025-8033. CrossRef Medline

Lee KW, Kim Y, Kim AM, Helmin K, Nairn AC, Greengard P (2006) Cocaine-induced dendritic spine formation in D1 and D2 dopamine receptor-containing medium spiny neurons in nucleus accumbens. Proc Natl Acad Sci U S A 103:3399-3404. CrossRef Medline

Lennette DA (1978) An improved mounting medium for immunofluorescence microscopy. Am J Clin Pathol 69:647-648. Medline

Lu L, Hope BT, Dempsey J, Liu SY, Bossert JM, Shaham Y (2005) Central amygdala ERK signaling pathway is critical to incubation of cocaine craving. Nat Neurosci 8:212-219. CrossRef Medline

Mameli M, Lüscher C (2011) Synaptic plasticity and addiction: learning mechanisms gone awry. Neuropharmacology 61:1052-1059. CrossRef Medline

Maze I, Covington HE 3rd, Dietz DM, LaPlant Q, Renthal W, Russo SJ, Mechanic M, Mouzon E, Neve RL, Haggarty SJ, Ren Y, Sampath SC, Hurd YL, Greengard P, Tarakhovsky A, Schaefer A, Nestler EJ (2010) Essential role of the histone methyltransferase G9a in cocaine-induced plasticity. Science 327:213-216. CrossRef Medline

McCutcheon JE, Wang X, Tseng KY, Wolf ME, Marinelli M (2011) Calcium-permeable AMPA receptors are present in nucleus accumbens synapses after prolonged withdrawal from cocaine self-administration but not experimenter-administered cocaine. J Neurosci 31:5737-5743. CrossRef Medline

Meisel RL, Mullins AJ (2006) Sexual experience in female rodents: cellular mechanisms and functional consequences. Brain Res 1126:56-65. CrossRef Medline

Muller DL, Unterwald EM (2005) D1 dopamine receptors modulate $\Delta$ FosB induction in rat striatum after intermittent morphine administration. J Pharmacol Exp Ther 314:148-154. CrossRef Medline

Nestler EJ (2008) Transcriptional mechanisms of addiction: role of $\Delta$ FosB. Philos Trans R Soc Lond B Biol Sci 363:3245-3255. CrossRef Medline

Nestler EJ, Barrot M, Self DW (2001) $\Delta$ FosB: a sustained molecular switch for addiction. Proc Natl Acad Sci U S A 98:11042-11046. CrossRef Medline

Olausson P, Jentsch JD, Tronson N, Neve RL, Nestler EJ, Taylor JR (2006) $\Delta$ FosB in the nucleus accumbens regulates food-reinforced instrumental behavior and motivation. J Neurosci 26:9196-9204. CrossRef Medline

Olsen CM (2011) Natural rewards, neuroplasticity, and non-drug addictions. Neuropharmacology 61:1109-1122. CrossRef Medline
Perrotti LI, Hadeishi Y, Ulery PG, Barrot M, Monteggia L, Duman RS, Nestler EJ (2004) Induction of $\Delta$ FosB in reward-related brain structures after chronic stress. J Neurosci 24:10594-10602. CrossRef Medline

Perrotti LI, Weaver RR, Robison B, Renthal W, Maze I, Yazdani S, Elmore RG, Knapp DJ, Selley DE, Martin BR, Sim-Selley L, Bachtell RK, Self DW, Nestler EJ (2008) Distinct patterns of $\Delta$ FosB induction in brain by drugs of abuse. Synapse 62:358-369. CrossRef Medline

Pitchers KK, Balfour ME, Lehman MN, Richtand NM, Yu L, Coolen LM (2010a) Neuroplasticity in the mesolimbic system induced by natural reward and subsequent reward abstinence. Biol Psychiatry 67:872-879. CrossRef Medline

Pitchers KK, Frohmader KS, Vialou V, Mouzon E, Nestler EJ, Lehman MN, Coolen LM (2010b) $\Delta$ FosB in the nucleus accumbens is critical for reinforcing effects of sexual reward. Genes Brain Behav 9:831-840. CrossRef Medline

Pitchers KK, Schmid S, Di Sebastiano AR, Wang X, Laviolette SR, Lehman MN, Coolen LM (2012) Natural reward experience alters AMPA and NMDA receptor distribution and function in the nucleus accumbens. PLoS One 7:e34700. CrossRef Medline

Roberts MD, Gilpin L, Parker KE, Childs TE, Will MJ, Booth FW (2012) Dopamine D1 receptor modulation in nucleus accumbens lowers voluntary wheel running in rats bred to run high distances. Physiol Behav 105:661-668. CrossRef Medline

Russo SJ, Mazei-Robison MS, Ables JL, Nestler EJ (2009a) Neurotrophic factors and structural plasticity in addiction. Neuropharmacology 56 [Suppl 1]:73-82.

Russo SJ, Wilkinson MB, Mazei-Robison MS, Dietz DM, Maze I, Krishnan V, Renthal W, Graham A, Birnbaum SG, Green TA, Robison B, Lesselyong A, Perrotti LI, Bolaños CA, Kumar A, Clark MS, Neumaier JF, Neve RL, Bhakar $\mathrm{AL}$, Barker PA, et al. (2009b) Nuclear factor $\kappa \mathrm{B}$ signaling regulates neuronal morphology and cocaine reward. J Neurosci 29:3529-3537. CrossRef Medline

Taylor JR, Lynch WJ, Sanchez H, Olausson P, Nestler EJ, Bibb JA (2007) Inhibition of Cdk5 in the nucleus accumbens enhances the locomotoractivating and incentive-motivational effects of cocaine. Proc Natl Acad Sci U S A 104:4147-4152. CrossRef Medline

Tenk CM, Wilson H, Zhang Q, Pitchers KK, Coolen LM (2009) Sexual reward in male rats: effects of sexual experience on conditioned place preferences associated with ejaculation and intromissions. Horm Behav 55: 93-97. CrossRef Medline

Thomas MJ, Kalivas PW, Shaham Y (2008) Neuroplasticity in the mesolimbic dopamine system and cocaine addiction. Br J Pharmacol 154:327-342. CrossRef Medline

Vialou V, Robison AJ, Laplant QC, Covington HE 3rd, Dietz DM, Ohnishi YN, Mouzon E, Rush AJ 3rd, Watts EL, Wallace DL, Iñiguez SD, Ohnishi YH, Steiner MA, Warren BL, Krishnan V, Bolaños CA, Neve RL, Ghose S, Berton O, Tamminga CA, et al. (2010) $\Delta$ FosB in brain reward circuits mediates resilience to stress and antidepressant responses. Nat Neurosci 13:745-752. CrossRef

Wallace DL, Vialou V, Rios L, Carle-Florence TL, Chakravarty S, Kumar A, Graham DL, Green TA, Kirk A, Iñiguez SD, Perrotti LI, Barrot M, DiLeone RJ, Nestler EJ, Bolaños-Guzmán CA (2008) The influence of $\Delta$ FosB in the nucleus accumbens on natural reward-related behavior. J Neurosci 28:10272-10277. CrossRef Medline

Werme M, Messer C, Olson L, Gilden L, Thorén P, Nestler EJ, Brené S (2002) $\Delta$ FosB regulates wheel running. J Neurosci 22:8133-8138. Medline

Winstanley CA, LaPlant Q, Theobald DE, Green TA, Bachtell RK, Perrotti LI, DiLeone RJ, Russo SJ, Garth WJ, Self DW, Nestler EJ (2007) $\Delta$ FosB induction in orbitofrontal cortex mediates tolerance to cocaine-induced cognitive dysfunction. J Neurosci 27:10497-10507. CrossRef Medline

Wolf ME (2010a) The Bermuda Triangle of cocaine-induced neuroadaptations. Trends Neurosci 33:391-398. CrossRef Medline

Wolf ME (2010b) Regulation of AMPA receptor trafficking in the nucleus accumbens by dopamine and cocaine. Neurotox Res 18:393-409. CrossRef Medline

Wolf ME (2012) Neuroscience: behavioural effects of cocaine reversed. Nature 481:36-37. CrossRef Medline

Xue YX, Luo YX, Wu P, Shi HS, Xue LF, Chen C, Zhu WL, Ding ZB, Bao YP, Shi J, Epstein DH, Shaham Y, Lu L (2012) A memory retrievalextinction procedure to prevent drug craving and relapse. Science 336: 241-245. CrossRef Medline

Zachariou V, Bolanos CA, Selley DE, Theobald D, Cassidy MP, Kelz MB, 
Shaw-Lutchman T, Berton O, Sim-Selley LJ, Dileone RJ, Kumar A, Nestler EJ (2006) An essential role for $\Delta$ FosB in the nucleus accumbens in morphine action. Nat Neurosci 9:205-211. CrossRef Medline
Zhang D, Zhang L, Lou DW, Nakabeppu Y, Zhang J, Xu M (2002) The dopamine D1 receptor is a critical mediator for cocaine-induced gene expression. J Neurochem 82:1453-1464. CrossRef Medline 